\title{
Entrepreneurial prospects and challenges for women amidst COVID-19: a case study of Delhi, India
}

Challenges of women entrepreneurs

\author{
Sanjeev Kumar
}

Department of Political Science, Shyama Prasad Mukherji College for Women, New Delhi, India and Institute of Lifelong Learning, University of Delhi, New Delhi, India, and Neha Singh

Department of Political Science, Mata Sundri College for Women, University of Delhi, New Delhi, India

\begin{abstract}
Purpose - This paper aims to encapsulate the gendered support and hindering factors along with the role of the state experienced by Delhi-based women entrepreneurs in setting up/operating their enterprises amidst the challenges posed by the coronavirus disease 2019 (COVID-19) pandemic.

Design/methodology/approach - The study used mixed methods to explore the challenges faced and recovery mechanisms adopted by women entrepreneurs with special reference to the COVID-19 pandemic. A total of 50 Delhi-based young women entrepreneurs (42 actual entrepreneurs +8 prospective/struggling entrepreneurs) selected using snowball/purposive sampling were studied through both a semi-structured questionnaire and personal interviews. National Small Industries Corporation (NSIC) and micro, small and medium enterprises (MSME) were consulted for the government's policy documents and data. The SPSS package was used for quantitative data analysis.

Findings - Low-budget/very small-scale women entrepreneurs face common as well as gender-based challenges in the context of the market, finance, social capital, family support and awareness in addition to accessing the state's resources/policies in both their startups and crisis situations, such as the COVID-19 pandemic. Although gender sensitization, entrepreneurial family background, and equal access to technology and the Internet has enabled women entrepreneurs to initiate, adapt, and scale their enterprises, male domination within the family, society, market, and state apparatuses is omnipresent and has served as a bottleneck for women-owned startups while hindering the recovery of their enterprises amidst the COVID-19 pandemic.

Research limitations/implications - The study was limited to exploring the challenges and prospects of Delhi-based women entrepreneurs at the beginning of their enterprises and amidst the COVID-19 pandemic. On the other hand, the study had access to data and facts announced by the Indian government. No data were available on the implementation of policies and programs, and therefore specific policy analysis was not attempted. However, the reachability and accessibility of government resources and policies were employed. Practical implications - The study highlights the complexity of patriarchy, which hampers women entrepreneurs in all family, society, market and state domains. Therefore, policy enactment and implementation and further research on women entrepreneurship are suggested to focus more deeply on the gender dimension.

Originality/value - The data used in this work comprised inputs from government sources as well as insights from fieldwork that have not been used by any other publication.

Keywords Entrepreneurship, Women, COVID-19, MSME, NSIC, Development and scaling

Paper type Research paper

(C) Sanjeev Kumar and Neha Singh. Published in Fulbright Review of Economics and Policy. Published by Emerald Publishing Limited. This article is published under the Creative Commons Attribution (CC BY 4.0) licence. Anyone may reproduce, distribute, translate and create derivative works of this article (for both commercial and non-commercial purposes), subject to full attribution to the original publication and authors. The full terms of this licence may be seen at http://creativecommons.org/licences/by/4.0/ legalcode
\end{abstract}

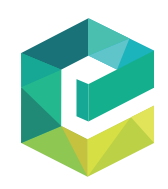

Fulbright Review of Economics and Policy Vol. 1 No. 2,2021 pp. $205-226$ Emerald Publishing Limite e-ISSN: 2635-0181 p-ISSN: 2635-0173 DOI 10.1108/FREP-09-2021-0057 
FREP

1,2

\section{Introduction}

The coronavirus disease 2019 (COVID-19) pandemic has severely affected the economic structure of the entire world, with women-owned enterprises suffering the most. UN Women has reported that by April 2021, job losses among rural Indian women working in the informal sectors had reached 80\% (UN Women, 2021; Abraham, Basole \& Kesar, 2021). During the lockdown in 2020, India's 6.33 crore micro, small and medium enterprises (MSMEs) faced a variety of risks due to breaks in the supply chain (Tankha, 2020), financial jeopardy, low sales and low demand for products (Mint, 2020). A 2020 study by Azim Premji University highlighted that urban self-employed enterprises suffered the most. Studies have also shown that women largely employed in the trading, service and informal sectors were much more adversely impacted during the lockdown. This clearly shows that COVID-19 has impacted women more than men, rural populations more than urban populations, and migrant and informal sector workers across the world, specifically in India (Azim Premji University, 2020; Bargotra et al., 202; Abraham et al., 2021).

The World Economic Forum's Global Gender Gap Index 2020 demonstrates that among 153 countries, India has slipped to the 112th position from the 108th position in 2018. Approximately 343 million women out of a total of 432 million working-age women in India are not paid for formal work. This also reflects the gender bias that has been present in India for ages. It is also estimated that by 2030, India's working-age population will surpass 1 billion, which would in turn lead to the economic potential of 400 million women being left unaddressed (Bain and Google, 2019). Notwithstanding the fact that the 6th economic census indicates that around $20 \%$ of all enterprises in India are owned by women, in actuality, most of these enterprises are nominally owned and largely managed by males.

Furthermore, it has been observed that the constitutional guarantee of gender equality in society, economy and politics has largely been compromised due to prevalent patriarchal values/structures (Milazzo \& Goldstein, 2019; Singh, 2021). This is further exacerbated by the misogynist attitudes prevalent in Indian society, which have resulted in highly unequal economic conditions and prospects for women and pose a serious challenge to one of the most important targets of the SDG 2030 agenda, namely gender equality. This challenge has been amplified during the COVID-19 pandemic, which has not only impacted women's mobility and dependency on their male counterparts or other men in society but has also exposed the government's inability to deal with gender-specific policy initiatives (OECD, 2020).

Amidst COVID-19, the patriarchal structure has reinvented itself in new forms, with the extent and modality of patriarchal domination being dependent on the situation. Women entrepreneurs differ from each other, and their entrepreneurship can be differentiated into four types based on the level and extent of assistance provided by males in society. In the first type of entrepreneurship, women lead the enterprise nominally, while their male family members make all of the decisions. In the second type, women own the enterprise but share the decision-making power with their male counterparts. In the third type, single women both own the enterprise and make all decisions on their own. In the fourth type, young women struggle to start and run their enterprises alongside wanted or unwanted interference by male/female family members. There are various ways to classify women entrepreneurs, but for the present study, the above four types were considered to explore the role of the state, family, society and the market in their entrepreneurial prospects.

This study focused on the availability of government schemes, particularly in relation with MSMEs and the National Small Industries Corporation (NSIC), to help women entrepreneurs in India. It also aimed to examine the major constraints and prospects faced by women in setting up and running Delhi-based enterprises, particularly during the COVID-19 pandemic. 
Indian Government's policy and entrepreneurship

Schemes such as the National Mission for Empowerment of Women, Leadership Development of Minority Women, Integrated Scheme for Women Empowerment, the Prime Minister's Rozgar Yojna (PMRY), the Swa-Shakti Project, Rural Women's Development and Empowerment, Rashtriya Mahila Kosh, Priyadarshani, and Women's Empowerment and Livelihood have been launched by the Government of India to provide employment to women. To promote the entrepreneurial prospects of women, the PMRY was initiated by the central government in 1993 to promote the self-employment of women by providing loans up to 1 lakh for business and 2 lakhs for industrial and agricultural activities (Lenka \& Agarwal, 2017). Additionally, institutions such as MSMEs, the State Small Industries Development Corporation (SSIDC) and the NSIC have also been playing a significant role in helping women entrepreneurs.

A report published by the Office of Development Commissioner (MSME) on July 20, 2021, highlighted the data of entrepreneurs registered under the scheme called "Udyam," [1] which consists of MSMEs from all over India. As per the report, currently, "35,29,084 MSMEs have been registered on the UDYAM registration portal till 30th June 2021, comprising 32,79,370 micro (93\%), 2,21,641 small (6\%) and 28,073 medium enterprises (1\%)" (Udyam, 2021). Out of the total of 3,297,717 MSMEs, micro-enterprises have invested less than INR 25 lakhs in setting up their enterprises. Similarly, 93,720 micro-enterprises have 25 to 50 lakhs of investment, and 66,314 micro-enterprises have approximately invested between 50 lakhs and 1 crore (Udyam, 2021).

On March 5, 2021, the Ministry of MSMEs made certain amendments to identify the types of enterprise and upgraded the registration provisions so that enterprises can receive support in their recovery from losses incurred during the COVID-19 pandemic. The NSIC has also taken significant steps, including signing memoranda with various business stakeholders, relaxing rules to ensure accessibility to government subsidies, permitting registration with the Udyam portal, providing loans and establishing incubation centers (NSCI, 2021).

\section{Women-owned entrepreneurship in India}

Over the decade, the percentage of women-owned enterprises has increased. India has a greater percentage of women-owned enterprises when compared to many other countries. As per the Udyam report, as of June, 2021, 81\% of MSMEs are owned by males, while $17 \%$ are owned by females (Udyam, 2021); 1\% are unrecognized in India. At present, women-owned enterprises in India have surpassed 15 million. The percentage of women-owned enterprises has grown from 14\% to 20\% over a decade (Bain and Google, 2019): 17\% are registered with Udyam, whereas 3\% are only registered with other agencies of the Government of India. Surprisingly, millions of women-owned MSMEs are still unregistered, as they do not fulfill the norms and instead fall under the category of self-employed and insufficiency of turnover (Pandey \& Pillai, 2020; Mehrotra \& Giri, 2019; Bargotra et al., 2021).

However, the $17-20 \%$ of women-owned enterprises that are registered as MSMEs face multiple challenges. A study by Bain and Google (2019) highlighted that there are 13.5-15.7 million women-owned enterprises in India, representing around $20 \%$ of the total enterprises and employing over 22 to 27 million people. Their study further pointed out that "several enterprises reported as women-owned are not controlled or run by women. A combination of financial and administrative reasons/benefits leads to women being 'on paper' owners with a little role to play” (Bain and Google, 2019; Gindling \& Newhouse, 2014). Furthermore, the study revealed that only 10-30\% of women-owned enterprises are actually run and managed by women (Bain and Google, 2019). Several factors hinder women entrepreneurs' prospects, such as social and family constraints, cultural control, lack of financial autonomy, lack of social networks and lack of exposure to the market. On the other hand, the most important
Challenges of women entrepreneurs 
FREP

1,2 characteristic of such enterprises is that out of total women-owned enterprises, $83 \%$ are single-person enterprises, while only $17 \%$ of enterprises employ hired workers out of the total $28 \%$ of enterprises that provide employment. Overall, in 9 out of 10 cases, the business has no employees besides the owner (Gindling \& Newhouse, 2014).

The study by Bain and Google demonstrated that around $69 \%$ of their respondents faced challenges posed by the social and cultural domains before starting their enterprises. However, such challenges are most prevalent in rural and highly traditional families. Despite the patriarchal structure present in the urban family structure, certain avenues are available for startups, but, unfortunately, they face other hindrances. Nonetheless, some sections of society consider patriarchy to be withering away and believe that the government has been proactive in expanding accessibility to common people, including women, to help them in their entrepreneurial exercise. Such a claim seems problematic, however, if we look at the data from the field.

\section{COVID-19 and policy responses in India}

The United Nations has explained that around 992 measures have been taken by 164 countries and territories. Among these measures, 177 have addressed challenges faced by women during the COVID-19 pandemic (UN Women and UNDP, 2020; Torres, Maduko, Gaddis, Iacovone \& Beegle, 2021; Hess et al., 2021). One of these measures, which has been implemented by various countries, including Brazil, Chile, India, Indonesia, Iran, Peru and Tunisia, are cash transfers "to low income and/or self-employed/informal workers adversely affected by the containment measures" (Loayza \& Pennings, 2020).

On March 26, 2020, the Government of India announced an economic relief measure of 1.7 lakh crore rupees (24 billion USD). Further support from the State Bank of India, the World Bank and the Asian Development Bank was also announced to support the Indian financial system. In May 2020, the Government of India announced an economic stimulus package worth 20 lakh crore (280 billion USD). In October and November 2020, the government again announced economic stimulus packages worth 29.87 lakh crore (420 billion USD) along with several other measures (The Economic Times, 2020; Rajat, 2020; The World Bank, 2020; Sharma, 2020) These economic relief packages were announced under the "Atmanirbhar Bharat" campaign.

Following the policy of targeted cash transfers, the Pradhan Mantri Garib Kalyan Yojna "under the Mahatma Gandhi National Rural Employment Act (MGNREGA), announced INR 1,000 ex-gratia payments to nearly 30 million poor senior citizens, widows and disabled as well as insurance coverage of as much as INR 50 lakh each to about 2 million healthcare workers" (The Economic Times, 2020). Such a policy of targeted cash transfers in middleincome developing countries, including India, has been praised by the World Bank. However, its actual reach to the targeted and needy beneficiaries needs proper reflection.

Apart from targeted cash transfers, employment-related measures have also been announced by the government. Two-thirds of the population was targeted for coverage under a food distribution program through the Public Distribution Scheme (PDS). The government also announced direct benefits to targeted individuals as well as creating 630,000 self-help groups (SHGs) to assist 70 million households, doubling collateral-free loans and providing LPG cylinders for three months to 83 million households. Certain directives to the states were also issued, such as a welfare fund that could be used for building and construction workers and District Mineral Foundation (DMF) funds worth 310 billion for use for victims of economic disruption because of the pandemic (KMPG, 2020).

The Government of India has also extended relief for organized sector employees and enterprises. The withdrawal limit for employees from the Employees Provident Fund Organisation (EPFO) has been increased to $75 \%$ of the account balance: "Establishments 
which employ up to 100 employees and if 90 per cent of whom earn up to INR 15,000 per month, the government will pay the employee provident fund contribution to both of the employer and the employee (12 per cent each) from March 2020 to May 2020. This support is extended for another 3 months i.e. June to August 2020" (KMPG, 2020). Relaxations to the withdrawal limit from the New Pension Scheme (NPS) were also introduced to aid in the recover from challenges created by the COVID-19 pandemic.

The Reserve Bank of India introduced liquidity measures on March 27, 2020 and April 17, 2020. These measures included a reduction in the repo rate and a reduction of cash reserve ratio (CRR) targeting to release "liquidity of worth 137000 crore across the banking system." These measures were expected to inject 4.74 lakh crore rupees of liquidity into the system (KMPG, 2020).

\section{Measures for MSMEs}

The government relaxed collateral-free loans with 100\% credit worth INR 3 lakh crore (39 billion USD). Major steps to assist MSMEs were taken, such as subordinate debt for stressed MSMEs worth INR 20 thousand crore (2.6 billion USD), INR 50 thousand crore (6.5 billion USD) of equity infusion, the introduction of a new definition of MSMEs, revising the investment limit upward, additional criteria of turnover, the removal of global tenders for government contracts up to INR 200 crore and seeking to clear MSME dues within 45 days. Furthermore, initiatives were also taken to encourage e-market linkages instead of trade fairs and exhibitions. Other major policy responses can be seen in terms of relief for nonbank financial companies (NBFCs) and power utilities, regulatory measures, relaxations to the real estate sector and Engineering, Procurement and Construction (EPC)/contractors, and revisions on insolvency and the bankruptcy code (KMPG, 2020). To specifically help MSMEs, the Government of India has introduced an amendment to remove the differentiation between the manufacturing sector $(36 \%)$ and the service sector $(64 \%)$ to help enterprises avail themselves of the benefits of MSME schemes (Udyam, 2021).

The Atmanirbhar Bharat Rozgar Yojna seeks to combine employability with an emergency credit guarantee. Under the Atmanirbhar Bharat Abhiyan, MSMEs have been given priority and better financial access. A total of INR 20,000 crore of subordinate debt for stressed MSMEs and INR 4,000 crore for a credit guarantee trust for micro and small enterprises have been announced under the Abhiyan. Consequently, as of 31.12.2020, "12 banks have been extended guarantees amounting to INR 17.66 crore to 178 borrowers and INR 50,000 crore equity infusion for MSMEs through Fund of Funds" have been announced (MSME, 2021).

\section{Women-specific policy measures}

Specific women-related special provisions have also been taken by the government. The 2020-2021 annual report of MSMEs mentioned that in 2018, the Indian government announced 12 key decisions, one of which was the Central Public Sector Undertakings (CPSUs) "to make mandatory procurement of 3\% from Women Entrepreneurs out of $25 \%$ mandatory procurement" (MSME, 2021). And, as of December 31, 2021, "CPSUs have procured goods and services worth INR 357.81 crore from 2374 women MSEs that work out to be $0.63 \%$ of the total procurement" (MSME, 2021). By this period, INR 5 lakhs were provided to micro-enterprises under the scheme Credit Guarantee Trust Fund for MSEs (CGTMSE), $80 \%$ of which was for MSEs owned/operated by women. Similarly, the Government of India also allocated $80 \%$ of the fund to help women entrepreneurs' associations to create marketing hubs (MSME, 2021).

The report also highlights how the government has been providing subsidies to womenowned enterprises from 2008 to December 31, 2021, under the scheme Pradhan Mantri Employment Guarantee Program (PMEGP). The report mentions that, under PMEGP, 
FREP

1,2 "higher subsidy is provided to women beneficiaries. Since inception (i.e. 2008-09 to 31.12.2020), a total of 1,86,370 projects have been assisted to women entrepreneurs under PMEGP" (MSME, 2021). As per the MSME Annual Report 2020-2021, under PMEGP, 4,930 micro-enterprises were benefited in 2008-2009, which, as of December 31,2020, had reached 25,434, 24,720, and 11,823 micro-enterprises by 2018-2019, 2019-2020 and 2020-2021, respectively (MSME, 2021). Similarly, various other schemes, such as loan credits, food distribution, cash transfers and collateral free loans, have been launched by the government to help women entrepreneurs recover from the impact of the COVID-19 pandemic. However, the actual delivery of these schemes to people has been a major challenge and lacks proper attention by scholars working in the field of entrepreneurship in India.

\section{Literature and framework}

Despite their socio-economic and political achievements, women across the world face patriarchal constraints at all levels, such as family, society, market and state institutions. The structures of patriarchy pose challenges to women's entrepreneurial prospects at both the beginning and during times of crisis. The most important challenge that women entrepreneurs face in setting up and running their enterprises is the lack of access to state resources and financial support (Menon, 2020; OECD, 2020; UN Women, 2020, 2021), and it is a well-known fact that there is a lack of equal opportunities for women that clearly reflects the traditional gender disparity. This unfair practice puts women at the margin when it comes to the question of accessibility to financial and other state resources (Singh, Farooquee \& Pattanaik, 2017; Gartner et al., 2004). Here, the lack of opportunity and accessibility to state support in terms of finance is not an economic issue alone but is also due to the patriarchal nature of state and capital holdings, which marginalizes women.

In various countries, some of the initiatives taken by governments to ease the formalization and registration processes for enterprises have had little impact in encouraging women entrepreneurs to launch startups, be profitable and access state assistance (Rothenberg et al., 2016; Galiani, Meléndez \& Ahumada, 2017), which have also been of little service to women in India during the COVID-19 pandemic. Scholars have not given enough attention to how government policies have failed to attract low-scale women solopreneurs and entrepreneurs in India.

The contribution of women's economic ownership to the economic development of the nation has been neglected (Reynolds et al., 1997; Duchénaut, 1997; Singh, 2020). Consequently, this has led to concerns over the adequacy and effectiveness of policy initiatives aimed at supporting women entrepreneurs and enabling them to access the state's resources and policies. Scholars who have sought to explore the reasons behind such neglect have found that most studies on women entrepreneurship have been conducted from a male-centric perspective (Taylor \& Newcomer, 2005).

Finance has been one of the most important spheres that has impacted startups as well as the risk bearing and scaling of women entrepreneurs. The lack of capital and reach to the financial resources of the state and markets serves as the greatest bottleneck for women entrepreneurs in South Asian countries (Maysami \& Goby, 1999; Ayadurai, 2006; Barwa, 2003; Karim, 2001). Scholars of "relative resources and bargaining power" have highlighted that the higher the earning capacity and share of the household income of an individual, the higher the bargaining power in the family (Lundberg \& Rose, 1999). However, very few systematic studies have covered how patriarchal structures within the family and society hinder the prospects of women entrepreneurship.

Additionally, women entrepreneurs have been facing multiple challenges not only in the domain of the market but also due to the omnipresence of patriarchy in the family, society and state institutions, both in normal times and during COVID-19 (Milazzo \& Goldstein, 2019; 
Singh, 2019; Fafchamps \& Quinn, 2018; OECD, 2020; UN Women, 2020; Pandey \& Pillai, 2020; Mehrotra \& Giri, 2019; Bargotra et al., 2021; Ebert, 2021). Jaychandran found that there is no separation of responsibility of very small-scale female business owners (micro-enterprises) at home and at the firm in developing countries. This is because "people cannot or do not decouple their business from the rest of their lives and maximize the business's profits" (Jayachandran, 2020). Such phenomenology has continued unabated during the COVID-19 pandemic. Jayachandran further suggested that "further research on women's interconnected decisions about their businesses and family's finances and their business and family obligations is an important priority for understanding and narrowing the gender gap in microenterprise performance" (Jayachandran, 2020).

The present paper is an attempt to extend the theoretical and conceptual premises provided by Jayachandran (2020), Bain and Google (2019), OECD (2020), UN Women (2020), Bargotra (2021), and Pandey and Pillai (2020) to investigate how women entrepreneurs face challenges and what recovery models have been attempted within the domains of family, market, society, non-state institutions and state institutions or premises amidst the COVID-19 pandemic in India. Therefore, the study designed the following framework, which evaluates relations among various stakeholders that impact the entrepreneurial prospects of women in normal times as well as during the COVID-19 pandemic.

\section{Methodology}

\section{Sample selection}

A total 50 women entrepreneurs (42 actual entrepreneurs +8 prospective/struggling entrepreneurs) were studied through structured questionnaires and personal interviews. The entrepreneurs sampled in this study were very small-scale entrepreneurs or what Jaychandran called microentrepreneurs, that is, having no employees or fewer than five employees in their enterprise (Jaychandran, 2020). The method of selection of the respondents was based on snowball sampling from Delhi targeting younger women entrepreneurs with

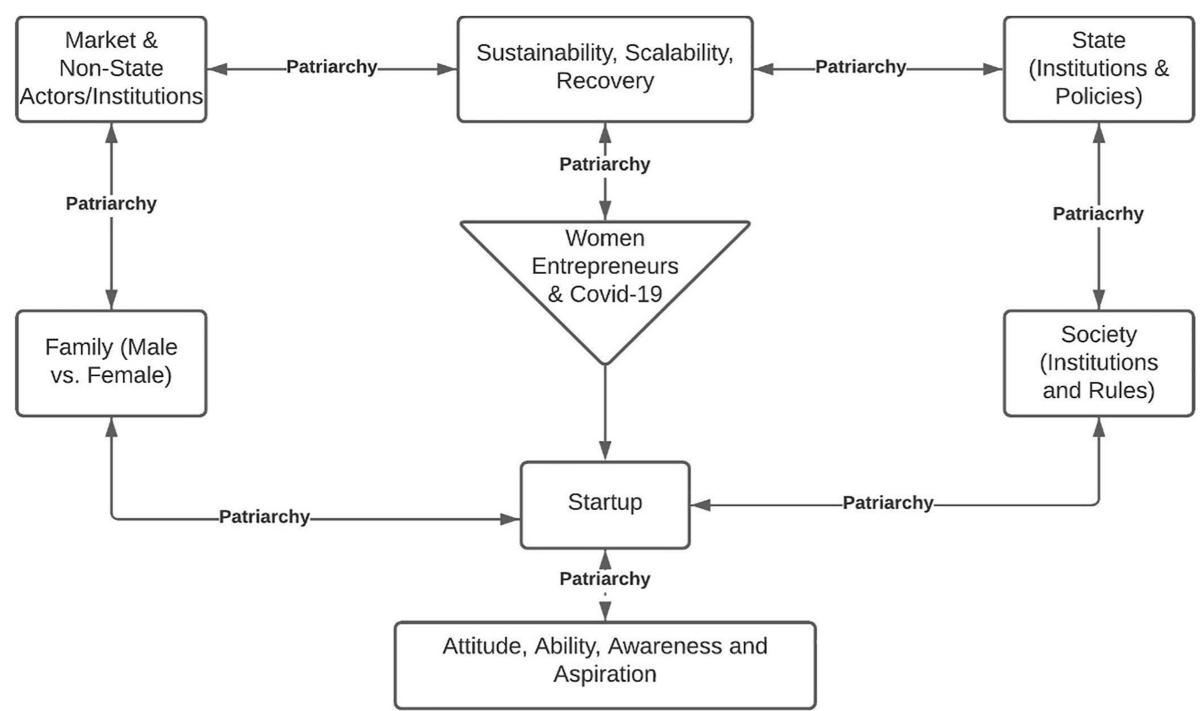

Challenges of women entrepreneurs

Source(s): Author's work

Figure 1. Research framework 
FREP

1,2

fewer than ten years of entrepreneurial experience. Therefore, more than $90 \%$ of the respondents were younger women who were new to the world of entrepreneurship. The other $10 \%$ of respondents were relatively older but did not have more than ten years of experience. The study interviewed 42 entrepreneurs through a semi-structured questionnaire along with eight prospective or failed entrepreneurs. The case study and data analysis were used to map the centrality of gendered components in the motivations, challenges and prospects for

\section{Data collection and analysis}

The data collection involved a methodological triangulation approach to combine policy documents and qualitative and quantitative data collection through semi-structured interviews. This approach helped to reduce preconceived assumptions and biases (Kabbaj et al., 2018) and to provide authenticity to the findings. For the policy documents, the data were collected from institutions such as the NSIC and the Ministry of MSMEs. To identify the respondents, personal and institutional contacts, social media and student alumni were used. The SPSS package was used to process the quantitative data. The names of the respondents were kept confidential and coded as WE1, WE2 ...WE10. These codes were used when discussing their narratives in this paper.

\section{Central question}

This study sought to explore how the common as well as patriarchal structures of the family, society, market and state apparatuses have functioned as (en)disabling factors for Delhibased women entrepreneurs in setting up, as well as running, their enterprises amidst COVID-19.

\section{Field observations and discussion}

\section{Establishing enterprises/self-employment}

The number of women entrepreneurs has recently grown in India, but the speed of such growth has not been satisfactory. Largely, three types of enterprises can be observed. The first are those enterprises that were set up more than 20 years ago, typically upon the initiatives of male family members, and whose decision making is still dominated by either the husband, a male in-law or another male member of the family. Such women entrepreneurs have successfully included their children in the family business, and they enjoy comparatively better autonomy, status and respect than new women entrepreneurs with no entrepreneurial family background.

The second type comprises those enterprises that were started around ten years ago and are more of a combined effort of both males and females. Such enterprises were typically set up by male family members but participation by women is more decisive compared to the first type. Such women-owned enterprises often face severe opposition from family members. The family members of such enterprises have also helped their sons and daughters to become entrepreneurs. The third type of women-owned enterprises are emergent and do not have a family background of entrepreneurship. Such new women entrepreneurs face opposition from all domains and strive hard to grow. Thus, as can be seen, the role of family members, friends, markets and state institutions greatly impact the establishment and operation of women-owned enterprises in India (Singh \& Saxena, 2000).

In the present study, women entrepreneurs were asked about who had helped or obstructed them from their family (male family members, female family members, either or both parents, and none) and/or from outside their family (NGOs, friends, the state, non-state institutions, and none) in setting up their enterprises. Of the respondents, $42.9 \%$ said that 
they received support and encouragement from female family members, $21.4 \%$ stated that they received support from male family members, $21.4 \%$ claimed that they received support from both parents and $14.3 \%$ stated that they did not receive support from any family member.

The above responses demonstrate that although the patriarchal structure is an important factor within the family, women entrepreneurs nonetheless received sufficient support from their family. That was also possible because $80-90 \%$ of the respondents came from entrepreneurial and business family backgrounds. The respondents also explained that they had been encouraged to launch a startup because their parents were either familiar with entrepreneurial growth or were aware of gender issues. Despite this, a significant number of respondents suggested that they received more support from female family members. Regardless of the amount of support they received, however, preference was given to male family members, typically sons. The logic behind this preference is that daughters are usually expected to ultimately migrate after marriage. Accordingly, women entrepreneurs are often discouraged in terms of sustaining their enterprise after marriage. Either male in-laws or husbands often assume the decision-making role in enterprises owned by women after marriage.

Regarding support from outside the family, $57.1 \%$ of respondents did not receive support from any state or non-state agencies or institutions, whereas $28.6 \%$ received support from friends and $14.3 \%$ received support from NGOs or SHGs. The respondents claimed that the state and other financial institutions had completely failed to extend support to prospective women entrepreneurs in setting up their enterprises. WE1, a young women entrepreneur and graduate from central Delhi explained that she started her jewelry design enterprise in 2018 with initial support from her parents. She was not aware, however, of the state's policy concerning assistance for startups or her prospects for receiving such assistance. Additionally, she received the majority of her support from her family and friends during the endeavor.

The respondents were asked whether they had received any support from the state and, if they had, what kinds of support they had received. If they had not received such support, they were asked about the possible reasons for this. Of the respondents, $78.6 \%$ replied that they had not received any support from the state to begin their enterprise. This sizeable percentage further prompted the question of what potential reasons could have hindered them from accessing the state's resources or policy. The responses revealed that $50 \%$ of the respondents lacked information or awareness about the state's policy, whereas $21.4 \%$ knew a little about the provision of loans but, due to lengthy paperwork, had failed to avail themselves of financial support from state institutions. The responses further revealed that $7.1 \%$ of respondents did not have enough annual turnover or other collateral. In contrast, $21.4 \%$ knew a little about loans but did not opt for them, as government or bank loans are considered to be an unnecessary burden or a risk.

Delhi has a significant number of women-owned very small-scale startups, such as online trading and service providers, but they do not feel comfortable associating with government institutions. Most importantly, registering an enterprise in Delhi is particularly challenging. WE2, from Tilak Nagar, is a graduate from the University of Delhi and runs a small garment manufacturing unit at her house with the help of her parents. Due to the COVID-19 lockdown, she had to start manufacturing demand-based products. She explained that she has been trying to register her enterprise with the government, but on many occasions the name of her brand has not been accepted by the portal or agency. This has been challenging, as a company or enterprise that is not registered with either the MSME, the NSIC or the Company Act cannot access the benefits of the government scheme. In this sense, the relaxation in the registration or formalization of firms or enterprises has not been easy in India, even amidst COVID-19, unlike what Rothenberg et al. (2016) and Galiani et al. (2017) have found in other developing countries. 
FREP

1,2

\section{4}

Obstruction in setting up enterprises

Most enterprises in developing countries are women-owned (Klapper \& Parker, 2011), the majority of which involve small-scale investment, sales and profit (Nix, Gamberoni \& Heath, 2016). Although the number of women-owned enterprises in India is increasing, the number of unpaid women labor jobs is also increasing (Bain and Google, 2019). The major reasons behind the growing number of unpaid woman labor, hindrances in launching startups and challenges to the scalability of women entrepreneurships in India are still under-researched.

As per the responses collected in this study, almost $90 \%$ of the women entrepreneurs who received support from their family had a family with a business or entrepreneurial background. Around $70 \%$ of these women have continued to expand their family business, while $30 \%$ have entered into different entrepreneurial startups. For all of these women, family support has been very significant in starting their enterprise. Despite their success or failure, opposition to setting up their enterprise has largely come from within their family.

Figure 2 shows that $64.29 \%$ of the respondents have faced challenges posed by male family members; however, 14.29 and $21.43 \%$ responded that they had faced either little or least opposition from their family, respectively. Women entrepreneurs who had no family background of entrepreneurship constituted 15\% of the sample. These women responded that they had faced absolute opposition by male family members. Interestingly, those women with a family background of entrepreneurship, despite their entrepreneurial success and achievements, had faced interference in decision-making due to the patriarchal nature of their family.

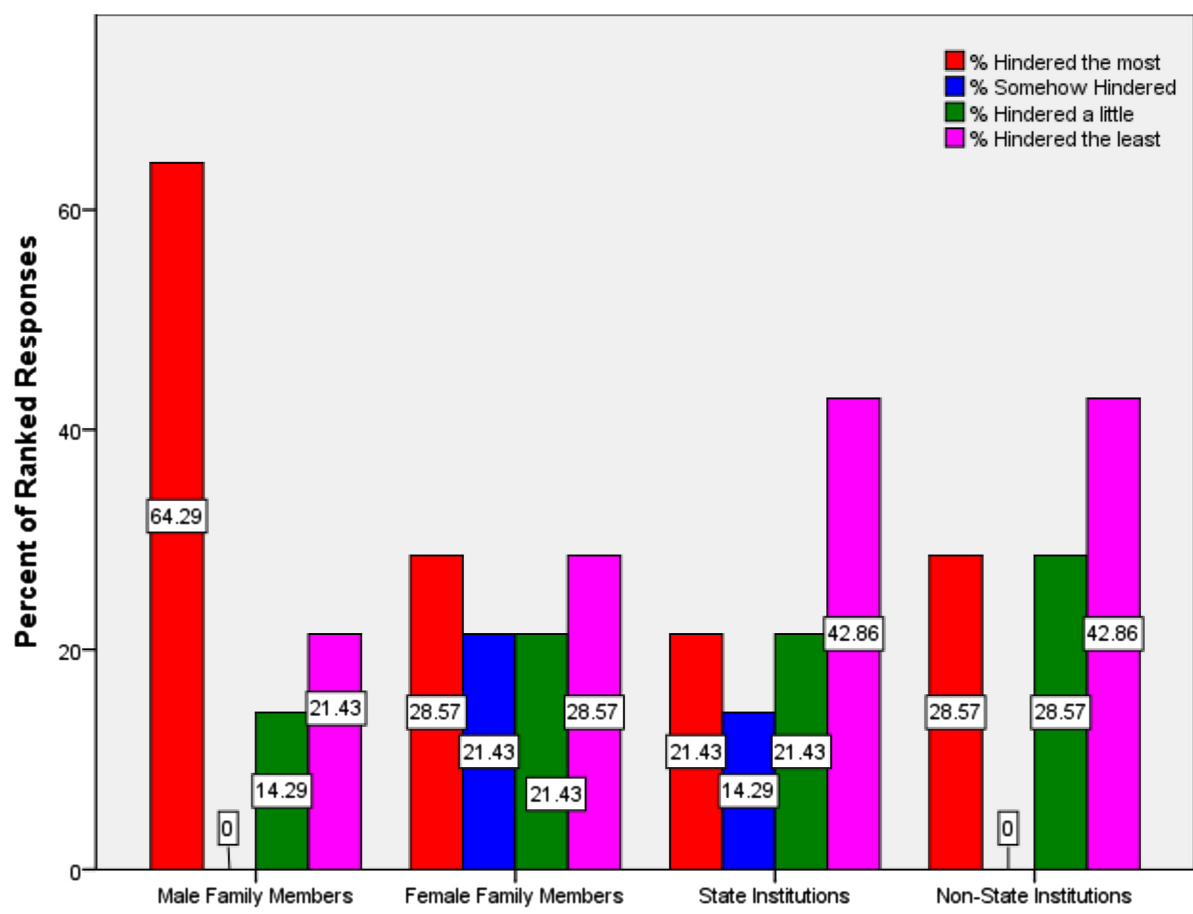

Source(s): Author's work

From field work data collected in July-August 2021, Delhi, India
Figure 2.

Factors that hindered women entrepreneurs in setting up their enterprises 
Interestingly, $28.57 \%$ of the respondents highlighted that they had faced some kind of opposition from female family members as well, whereas $21.43 \%$ stated that they had faced a little opposition by female family members. Female opposition to another female in her entrepreneurial endeavor confirms how the patriarchy is not merely a matter of male dominance and superiority but is significantly promoted by female agency as well.

Women entrepreneurs' lack of access to state or non-state institutions is caused by either unawareness or unwillingness. Figure 2 demonstrates that $42.86 \%$ of the respondents stated that both state and non-state institutions "hindered the least" to women entrepreneurs. However, $21.43 \%$ found state institutions to be the most hindering factor in setting up their enterprises, while $28.57 \%$ found non-state institutions to be the most hindering factor.

WE3, a postgraduate running a beauty-related product marketing firm, stated that she never thought to take state support as she was initiating her small enterprise. However, when she sought to enter the manufacturing sector, she wanted financial support from the state but, due to various obstacles, she could not receive it. She also tried to receive financial support from some NGOs, but she ultimately only received some guidance and advice.

As per the claims of liberal theorists, the state is neutral in the domain of markets, whereas liberal egalitarians support welfarist intervention by the state. A semi-welfare state such as India claims to be pro-market and to provide opportunities for people to accelerate their participation in enterprises, but the present study suggested other sides to this reality. More specifically, the study found that despite several initiatives by the state, adequate and proper policy implementation is lacking, and thereby a large number of women entrepreneurs cannot access the state's institutions and policies.

To explore further, young women entrepreneurs were asked about how the state has functioned as either an enabling or hindering factor. Of the respondents, $50 \%$ said that they lacked information related to state and non-state resources that could have helped them to set up their enterprises. Another $21.4 \%$ of respondents claimed that documentation and bureaucratic hurdles had hindered them, while $7.1 \%$ expressed that a lack of adequate annual turnover and the unavailability of collateral for mortgage had hindered them from availing themselves of support from state policies. Interestingly, $21.4 \%$ of the respondents stated that they had not sought any help from state or non-state institutions. This is because these respondents were aware of bureaucratic and other hurdles. In this context, WE4, a master's student at the University of Delhi who runs a small clothes-designing unit in North Delhi, highlighted that her lack of information regarding the state's policies was an important hindering factor. She added that when she had become familiar with the financial and other support available for registered institutions in the Udyam portal, she found that such support was allocated for bigger enterprises having more than 10 million rupees in annual turnover. She did not find any policy that would have helped low-budget startups or enterprises. This is the case with many very low capital micro-enterprises, which continue to lack access to support from state policies.

\section{COVID-19 and women entrepreneurship}

Scholars have demonstrated that women entrepreneurs face common masculine constraints worldwide in areas such as risk-bearing capacity, creativity, innovative leadership roles and adaptation to changing economic systems (Kjeldsen \& Nielson, 2000; Taylor \& Newcomer, 2005; Gupta \& Aggarwal, 2015). These constraints and associated stereotypes have become more prominent during the COVID-19 pandemic due to various restrictions, including mobility.

Constraints such as loss of finances, labor forces and brand values, as well as the death of loved ones and the burden of managing the family during the pandemic have also disproportionately impacted women. Burdens from both sides, at home and in the market, 
FREP 1,2

\section{6}

have damaged women entrepreneurs the most. COVID-19 has had a severe impact on smallscale women workers involved in trading, tailoring, dressmaking and shopkeeping, as well as women working in beauty parlors, as receptionists, in daily wage work, and in the service sectors. Studies have emphasized that approximately 17 to 19.3 million women became unemployed during the pandemic lockdown between March and April 2020. Unemployment among women increased at a rate 13\% higher than that of their male employees (Misra and Patel, 2021; Abraham et al., 2021; Bargotra, Bhatotia, Karthick \& Narasimhan, 2021). In this regard, this part of the study explored the support system for women entrepreneurs amidst COVID-19 in India, particularly in Delhi.

The respondents were asked to what extent family, society, the state and non-state institutions, such as NGOs, had been helpful to women entrepreneurs during the COVID-19 pandemic and the ways in which they had sought to recover from the impact of the pandemic. Figure 3 highlights the data analysis of the ranked responses.

Among the total sample, $35.71 \%$ of the respondents highlighted that male family members had supported their enterprise, whereas $42.86 \%$ had received minimal support from male family members. The reason behind such a response was explained by one of the

Figure 3.

Factors that supported women entrepreneurs amidst the COVID-19 pandemic

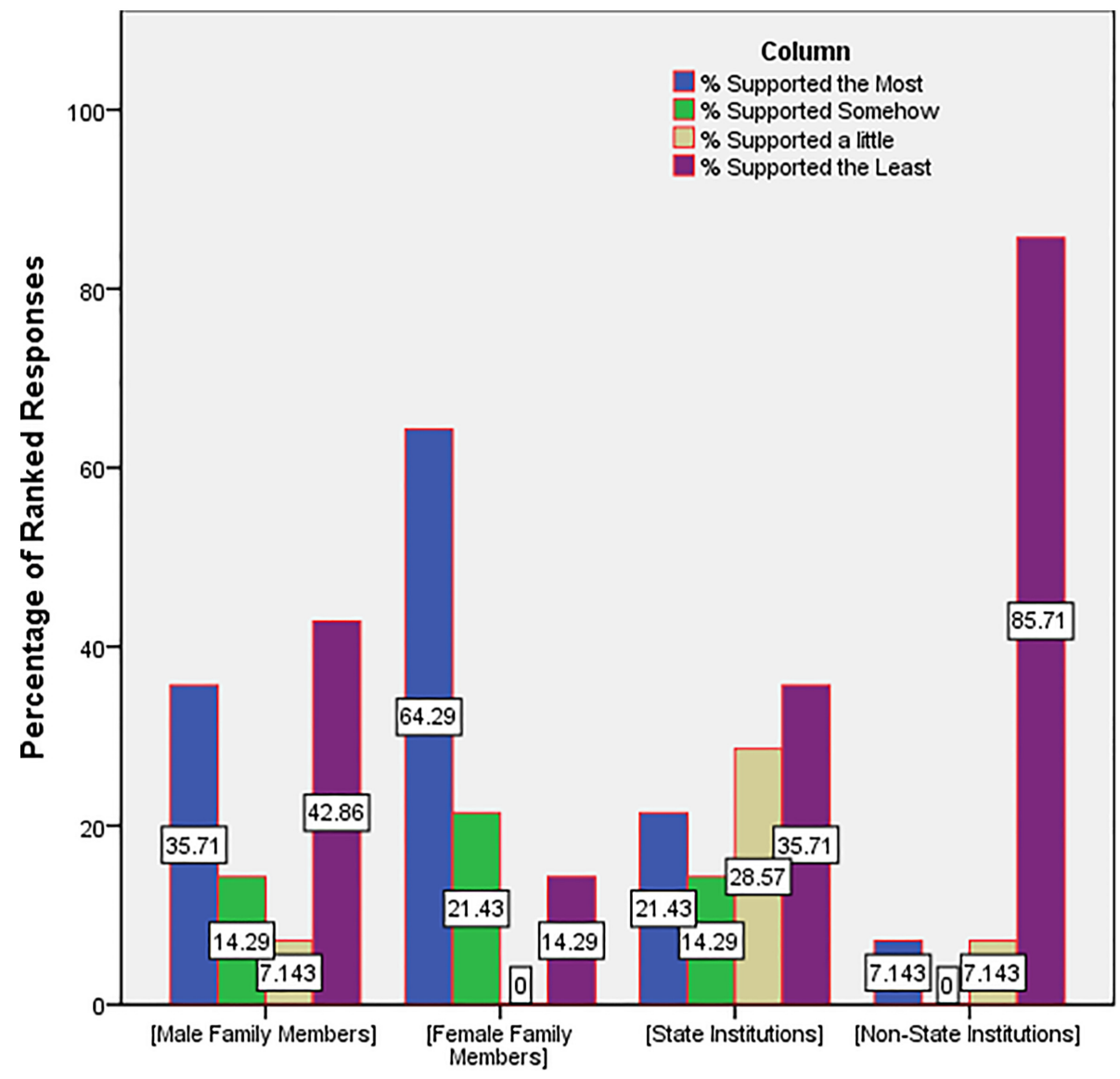

Source(s): Author's work From field work data collected in July - August 2021, Delhi, India 
respondents, WE5, who had completed her MBA from a renowned institution and was running both a company and an NGO. She experienced a double burden in that she had to both manage family affairs at home and navigate entrepreneurial challenges in the market. However, she had received sufficient support from both female and male family members. But comparatively, male family members were more concerned about her managing family affairs and less so about her entrepreneurial responsibilities. Figure 3 also shows that $64.29 \%$ of the respondents found their female family members to be very supportive, $21.43 \%$ found them to be somewhat supportive and $14.29 \%$ found them to be minimally supportive.

It should be noted that family support in setting up enterprises was strengthened during the COVID-19 pandemic. Of the respondents, $42.9 \%$ had received support from female family members prior to the pandemic, whereas during COVID-19, $64.29 \%$ of respondents had received support from female family members. Interestingly, support from male family members also increased - by $14 \%$, that is, $21.4 \%$ of the total respondents supported female family entrepreneurs at the time of setting up of the enterprises, whereas $35.7 \%$ of the total respondents extended support to female family members at the time of the covid-19 pandemic. In other words, support by female and male family members increased for $22 \%$ and $14 \%$ of the respondents, respectively, during the pandemic. Although the amount of support by female family members was greater than that by male family members, the fact that support by male family members was nonetheless still provided indicates an important transformation and acceptance of the growing economic status of women entrepreneurs and their bargaining power within the family, as suggested by Thomson (1990) and Lundberg and Rose (1999).

The support system provided by state and non-state financial institutions remained very ineffective. Merely $21 \%$ of the respondents indicated that the state had been supportive, whereas $35.71 \%$ said that the state was minimally supportive. On the other hand, $85.7 \%$ of respondents said that non-state financial institutions were minimally supportive. The reason for this was mentioned by one of the respondents. WE6, who has successfully run an essential goods marketing enterprise, stated that the state was supportive only in terms of providing an e-pass and permitting her to operate alongside COVID-19 norms. However, no relaxation or financial support from the state was provided.

In terms of recovery from the loss of enterprises or jobs, the World Bank has reported that $20 \%$ of those who had either formal or informal jobs but had lost their employment during COVID-19 have shifted to self-employment (The World Bank, 2020b). It has also been highlighted by studies that the loss of finances, the postponement of loans and other difficulties have been more severe for women-owned enterprises than their male counterparts, but at the same time, women entrepreneurs have also shown more confidence in recovery, re-establishment or a business shift of their enterprises in the future (Buteau \& Chandrasekhar, 2020; Chawla, Sahni \& Sadhwani, 2020; Sunil, 2020).

In this context, the present study sought to more deeply explore how women entrepreneurs could gain confidence and access support systems, and what strategies they have applied to recover from the effects of COVID-19. The respondents suggested that many women entrepreneurs in the manufacturing sector had to change their production strategy as per changes in demand. Although they did not receive any support from the government or other financial agencies, they did receive better moral and/or financial support from both male and female family members during COVID-19 than they had at the time they were setting up their enterprises.

For example, WE2, who has been managing her family business in Tilak Nagar, Delhi, received sufficient support from her parents. Her business, which specializes in the designing of clothes, had been hampered in all aspects by the pandemic. In response, she changed her production strategy and started manufacturing masks, which allowed her to sustainably manage her enterprise. She also attempted to expand her customer base using online advertisements for marketing, but had little success in this endeavor. 
FREP

1,2

218

WE7, who runs an event management company, faced great losses during the pandemic. She sought to organize online events, but this effort failed. It should be noted that online services for education and entertainment, among other industries, have been successful, but have not helped manufacturing enterprises. It has also been observed that very micro-level startups have been able to change their production and service strategies, whereas bigger enterprises have not been able to do so because of their specialized services and manufacturing units. The respondents who were working in the service sectors changed their service delivery system and slowly tried to recover. But in all of these contexts, support from the self-sustaining market and state was invisible.

A study by Bargotra et al. (2021) suggested that there has been a desire for low risk among women entrepreneurs. Almost $80 \%$ of the respondents had no loan obligation from any state agency and, during the COVID-19 pandemic, rarely sought to take out loans from the state due to the nonavailability of even small-size tickets if not collateral-free loans. Instead, they preferred to subsist on either their own savings or through other channels even before seeking help from family and friends (Bargotra et al., 2021). The findings from the present study also suggest that the policy initiatives of the government in 2020 , which included a tremendous amount of financial disbursements to help MSMEs, have not been successful in reaching the vast majority of the needy and very small-scale women (solo) entrepreneurs. This was due to not meeting the requirement criteria pertaining to the size of the enterprise, annual turnover, registration with Udyam, the desire for low risk and lack of awareness among women entrepreneurs.

\section{Patriarchal structure of family, society, market and state}

To explore the perceptions of women entrepreneurs about the nature of patriarchy and its deep embeddedness in the family, society, market and state institutions, which have had an impact on their entrepreneurship endeavors, the study asked whether the patriarchy in these sectors has functioned as the biggest barrier, one barrier or no barrier at all. Concerning this, as Figure 4 shows, $28.57 \%$ of the respondents stated that the patriarchy in the family was the biggest barrier, whereas $14.29 \%$ found it to be one barrier to their enterprise. However, $57.14 \%$ of the respondents claimed that the patriarchy in the family posed no barrier to their enterprise.

Here, one interesting narrative came from WE8, a postgraduate from the University of Delhi who was running a beauty salon with five employees in South Delhi. She stated that "purush to chahte hain ki mahila bhi kam kare jisase ghar me double paise ayen. Hame to ghar me aur bahar dono jagah kam karna padta hai. Par ek bat hai ki, mere paise earn karne ke karan ghar me koi mujh par dbaw nahi dal sakta." (Male members do like women to work, because if women work then double income comes home. We, women, are supposed to work both at home and outside also. However, I have come to the realization that no one can overpower me since I am working and earning).

Women entrepreneurs in Delhi appear to have no substantial issue with the patriarchal societal structure. Merely $7.14 \%$ of the respondents believed that society's patriarchal structure had anything to do with their enterprises, while $64.29 \%$ claimed that society's patriarchal structure was no barrier at all to their enterprise. But interestingly, $28.57 \%$ of the respondents believed that society itself acts as a barrier to their enterprise. This claim contradicts the study by Bain and Google (2019), which observed that "All segments of entrepreneurs, as well as non-entrepreneurs, face severely inhibiting cultural constraints. These manifest in the form of denial of the social permission to work and gender biases that persists widely." When explored further, the respondents suggested that, first, the smaller scale of their enterprise in terms of involvement with the market decreased the potential to face the hurdles posed by patriarchy in society and the market. But when the women 


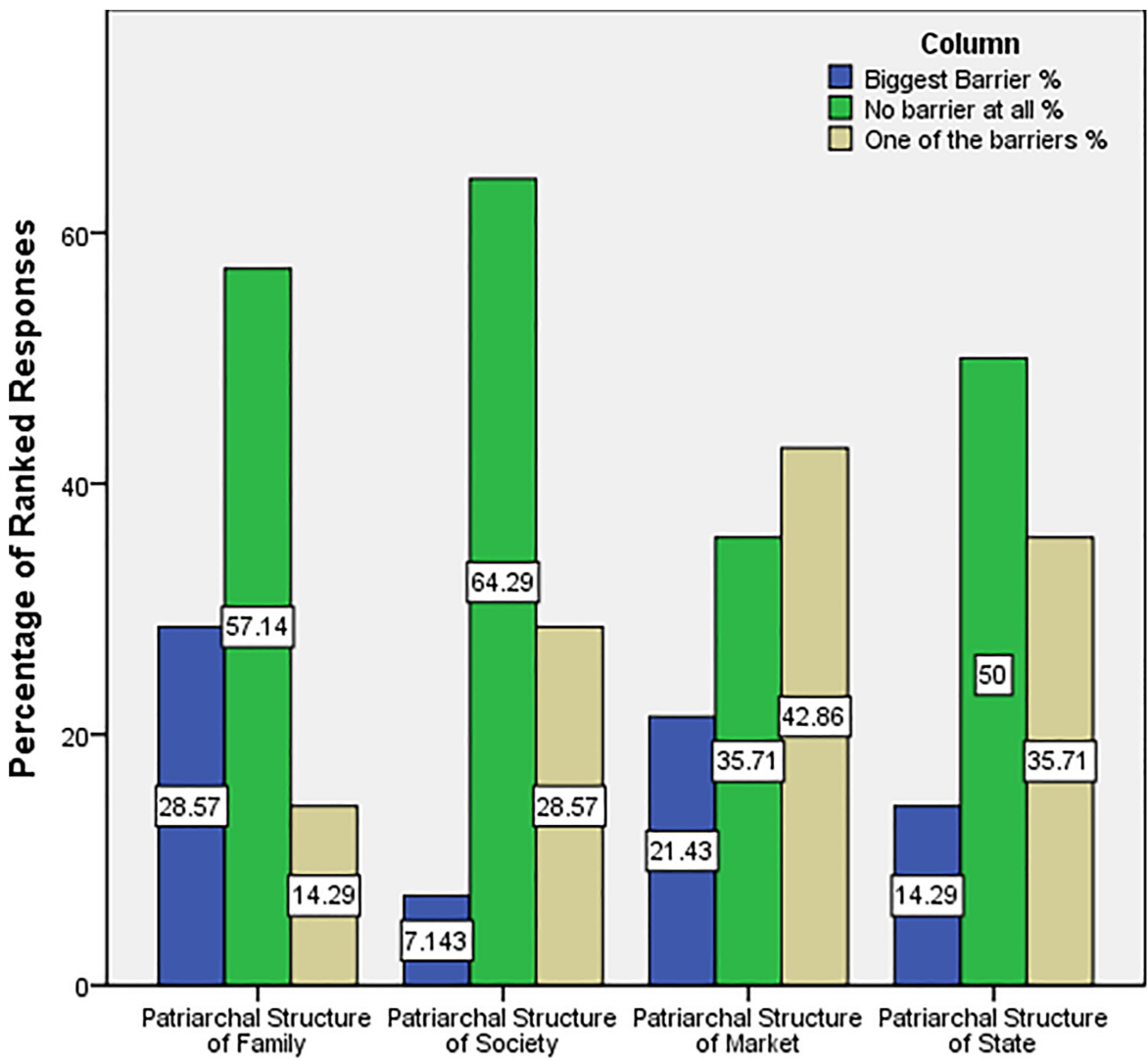

Source(s): Author's work

From field work data collected in July - August 2021, Delhi, India
Challenges of women

entrepreneurs

Figure 4.

Perception of respondents on the patriarchal structure of family, society, market and state

entrepreneurs scaled upward, patriarchal instincts in the market and society began to hinder their prospects due to the fear of competition and challenges to male domination. Second, Delhi, although a metropolitan city, is nonetheless still dominated by old traditions, cultural norms and customs. Therefore, interference by society in the affairs of people, especially women, does not occur until or unless their actions pose a threat to the larger structure of patriarchy commonly shared in metropolitan spaces. The types and modalities of patriarchy in metropolitan cities represent a good topic for further, prospective studies.

In other words, it appears that patriarchy is not visible until or unless its structural domination is threatened. It can also be observed from the narrative of WE8 that male members of society do not have a problem with women earning and spending at home; similarly, society has no real issue with women working until or unless their jobs, entrepreneurial ambitions and market competitiveness is viewed as a threat to male domination.

The problem of patriarchy becomes more visible in the market, as $21.43 \%$ of the respondents found that the market was permeated by patriarchal values and thereby represented the most significant barrier. Interestingly, $42.86 \%$ of the respondents found the patriarchal structure of the market to be one of the barriers they faced apart from financial, family and other constraints. 
FREP

1,2

A study by the International Centre for Research on Women (ICRW) highlighted that the roles males play in the market system is important for risk reduction. The study observed that "Interestingly women's ability and confidence to take risks seems to be dependent on having family support for their businesses. Women are willing to take slightly higher risks when they have strong support from families and in some cases male business partners" (ICRW, 2014).

Here, we sought to inquire about how the market's patriarchy works against women entrepreneurs. This was explained by one of the respondents, WE9, who runs a successful enterprise in the manufacturing sector. She stated that manufacturing is not an issue, but once entering the market, her male counterparts always considered women as incompatible in terms of deal making. They believed that they were superior and always told women "madam apko pata nahi market me humlog jyada ghumte hain, hame pata hain. App kisi purush ko lao jo deal kar sake unko pata hota hai market ke utar chadaw" (Madam, you don't know what happens in the market, we males move around in the market more so we know more. You please ask some male person to come and make a deal, they know more about the ups and downs and other technicalities of the market). She further highlighted that, many times, it is humiliating how the males in the market seek to demean women and consider them to be unworthy of marketing.

Finally, the patriarchal structure of the state has also worked to a certain extent to obstruct the entrepreneurial endeavors of women. As per Figure 4, 14.29\% of the respondents claimed that the state acts as the biggest barrier, whereas $35.71 \%$ claimed that the state's patriarchal structure was one among other barriers. In this sense, WE10 emphasized how state institutions are also male-centric; they do not consider women to be capable of taking out a loan and providing a sufficient guarantee against the loan. In many cases, property ownership is not afforded to women, and financial institutions deny any kind of loan or financial support in this regard. Therefore, the entire structure of the patriarchy, from the family to the state, is not bifurcated but instead neatly intertwined to create burdens and difficulties for women entrepreneurs in their efforts to initiate, scale and excel in their enterprises.

\section{Conclusion and recommendation}

Scholars have explained that women entrepreneurship serves a dual purpose. First, it empowers women; second, it adds to national economic growth (Sethi, 1998; Kritikos, 2014; Duchénaut, 1997). The NITI Ayog's report highlighted that "if India is able to address gender inequality - we could add about $\$ 770$ Billion to the GDP or about $18 \%$ more than the usual scenario" (NITI Ayog, 2021). As per the International Monetary Fund's estimate, if India were to manage to ensure equal participation of women in the labor market, then the country's GDP would increase by 27\% (Ebert, 2021). The study by Bain and Google (2019) also explained that despite substantial growth in the number of women entrepreneurs over the last decade, approximately $80 \%$ of women in the labor force are still not paid for formal work, and if this situation does not change, then by 2030 almost 400 million women will be unemployed. This situation has placed India in the 112th position in the Global Gender Gap Index, 2020.

The Indian government has launched many programs and policies to accelerate the process of providing employment to women and to help existing women entrepreneurs to scale (Lenka \& Agarwal, 2017; Udyam, 2021; NSIC, 2021). To help common people during the COVID-19 pandemic, programs such as targeted cash transfers, food security, subsidies, and easing conditions for loans and employment protection have been launched (The Economic Times, 2020; Rajat, 2020; The World Bank, 2020; Sharma, 2020; KMPG, 2020) by the Indian government under the Atmanirbhar Bharat campaign. To help enterprises, the Indian 
government has also relaxed loan facility, liquidity and equity infusion in various sectors (KMPG, 2020; Udyam, 2021; MSME, 2021). However, to help women entrepreneurs specifically, the government has reduced the mandatory procurement from $25 \%$ to $3 \%$ for women-owned enterprises and announced the CGTMSE (MSME, 2021).

However, policy initiatives to help women-owned enterprises as well as the national economy have failed to serve a large number of very small-scale women entrepreneurs in both normal times and amidst the COVID-19 pandemic. Many of these enterprises have not been registered or have insufficient annual turnover to avail themselves of the benefits of government schemes (Pandey \& Pillai, 2020; Mehrotra \& Giri, 2019; Bargotra, 2021). All of these enterprises have suffered financial losses during the pandemic, but the recovery rate of women-owned enterprises has been $8 \%$ less than that of male-owned enterprises (Abraham et al., 2021; Azim Premji University, 2020). It has also been highlighted by scholars and by the findings of the current study that most prospective as well as existing women entrepreneurs are either unaware of the policies of the government or have failed to take advantage of them, either willingly and unwillingly, because of bureaucratic hurdles and lengthy paperwork. Other works have also shown that a large number of enterprises are only nominally owned by women - in reality, they are managed and run by male family members. Here, the existing scholarship on the question of women-owned enterprises in India and specifically Delhi indicates that renewed research attention be paid to the phenomenology of women-owned enterprises, their barriers, and their prospects in both normal times and amidst the COVID-19 pandemic.

Against this backdrop, this study has explored how four agencies, that is, family (male and female) members, society (including friends and peer groups), markets and state institutions, have helped or obstructed women entrepreneurs in setting up, scaling, as well as recovering from the impact of the COVID-19 pandemic. The responses showed that the challenges for women entrepreneurs are the result of the omnipresence of the patriarchal structure, which has only been amplified during the pandemic. The patriarchal challenges for women entrepreneurs are very subtle and affect women's entrepreneurial prospects since the beginning of their enterprises.

A large number of women entrepreneurs come from an entrepreneurial family background and thereby do not receive much opposition on the family front. However, despite having a positive family environment, compared to male family members, women family members have less freedom, support and authority in decision-making related to their enterprises. In such cases, women experience the double burden of managing their family as well as their business affairs. Within the family, women receive more support from female family members compared to male family members, both in setting up their enterprises and recovering from the COVID-19 pandemic. But interestingly, in cases where there is no entrepreneurial family background, equal and sometimes greater opposition comes from female family members.

Since Delhi is a metropolitan city with a mixture of various communities, a proper and stable social formation has not yet been realized. Social constraints have become more prominent in the ghettos and rural spaces, where old, established, traditional and cultural norms and customs are threatened by women entrepreneurship. Therefore, most of the respondents did not receive any support from society - on the contrary, they experienced numerous social constraints. But importantly, peer groups and friends played a very important role for women entrepreneurs in recovering from the COVID-19 pandemic.

Most of the respondents suggested that the state has failed to provide any support to them for their startups as well as for recovering from the COVID-19 pandemic. The policy initiatives implemented by the government in terms of collateral-free loans, subsidies, liquidity and other measures have failed to reach very low-scale solopreneurs or women entrepreneurs. These policy measures have also failed in terms of understanding the actual needs of women entrepreneurs or in being readily accessible. Thus, there is a sustained need 
FREP 1,2

for coordinated efforts across state institutions (national, state and local governments), banking and other financial institutions, and educational as well as social institutions to remove barriers and ensure the accessibility of women to government policies in their startups, sustenance and scaling. Specially designed policy measures are also needed to extend support to old, new and prospective women entrepreneurs, particularly in recovering from the COVID-19 pandemic. The state's support in terms of finance, subsidies and security also requires special attention.

Finally, specific recommendations can be given based on the field data and observations. First, constraints against the entrepreneurial prospects of women from the beginning, as well as against scaling in times of crisis, such as COVID-19, are posed by patriarchal intentions and the patriarchal structure of the family, society, market and state apparatuses. Thus, any gender-neutral policy, although important, is insufficient to ensure justice and encourage women entrepreneurship, specifically in the context of recovery from the COVID-19 pandemic. Therefore, specific gender-based policy enactment is of utmost significance.

Second, the government's economic policy is not sufficient to ensure the recovery of women entrepreneurs. Policy intervention to raise gender awareness and the role of mainstreaming women labor in the development of the national economy at the family, society, educational and religious levels is crucial.

Third, de-gendering the market system is very important to ensure respect, encouragement and scalability for women entrepreneurs in the national interest. Finally, the most important goal is to remove the patriarchal conscience and orient the next generation, in both families and schools, for entrepreneurial prospects. Herein, a type of pedagogy needs to be developed and introduced at the school and college levels so that the SDG 2030 goal of gender equality can be met by protecting existing and supporting prospective women entrepreneurs in India.

Fourth, the state is strongly recommended to include gender concerns in all policy initiatives to ensure the better recovery of women entrepreneurs from the impact of COVID19 as well as the growth of the national economy and employment for the next generation.

Finally, future researchers should explore how the individual policies of the government and behavioral aspects of the family, society and market are driven by patriarchal and other discriminatory intentions that hinder the entrepreneurial prospects of women and determine how such hindrances can be eliminated.

\section{Note}

1. As per RBI Notification No. RBI/2020-2021/26, "Udyam registration is mandatory to avail benefits under most of the schemes of Ministry of MSME and availing credit from financial institutions." The notification is available at https:/www.rbi.org.in/Scripts/BS_CircularindexDisplay.aspx?Id=119511 For more details, see https://udyamregistration.gov.in

\section{References}

Abraham, R., Basole, A., \& Kesar, S. (2021). Tracking employment trajectories during the covid-19 pandemic: Evidence from Indian panel data. Working Paper 35. Centre for Sustainable Employment, Azim Premji University. available at: https://cse.azimpremjiuniversity.edu.in/wpcontent/uploads/2021/01/Abraham_Basole_Kesar_Covid_Trajectories_Jan_2021.pdf (accessed 16 September 2021).

Ayadurai, S. (2006). An insight into the 'constraints' faced by women entrepreneurs in a war-torn area: Case study of the northeast of Sri Lanka. Journal of Asia Entrepreneurship and Sustainability, 2(1), 1.

Azim Premji University (2020). COVID-19 Livelihoods Survey: Compilation of Findings. Bengaluru, available at: https://cse.azimpremjiuniversity.edu.in/wp-content/uploads/2020/06/Compilationof-findings-APU-COVID-19-Livelihoods-Survey_Final.pdf (accessed 13 September 2021). 
Bain and Google (2019). Powering the economy with her. Women entrepreneurship in India, available at: https://www.bain.com/insights/powering-the-economy-with-her-womenentrepreneurship-inIndia/ (accessed 20 June 2021).

Bargotra, N., Bhatotia, K., Karthick, M. P., \& Narasimhan (2021). How did the Indian women enterprises fair during Covid-19 lockdown?. Economic and Political Weekly, 56(19), 8 May, 2021, available at: https://www.epw.in/engage/article/how-did-indias-women-enterprises-fare-duringcovid (accessed 12 July 2021).

Barwa, S. D. (2003). Impact of Start your Business (SYB) Training on Women Entrepreneurs in Vietnam, Hanoi. Vietnam: ILO Office in Vietnam.

Buteau, S., \& Chandrasekhar, A. (2020). Covid-19: Assessing vulnerabilities faced by microenterprises. Ideas for India, 31 July, available at: https:/www.ideasforindia.in/topics/macroeconomics/covid19-assessing-vulnerabilities-faced-by-microenterprises.html (accessed 13 September 2021).

Chawla, M., Sahni, P., \& Sadhwani, K. (2020). Can Covid-19 be the turning point for women entrepreneurs in India?. Bain, 13 October, available at: https:/www.bain.com/insights/cancovid-19-be-the-turning-point-for-women-entrepreneurs-in-india/ (accessed 15 December 2020).

Duchénaut, B. (1997). Women Entrepreneurs in SMEs. Rennes: Euro PME.

Ebert, M. (2021). Women entrepreneurs' resilience in times of Covid-19. Deutsche Gesellschaft für Internationale Zusammenarbeit (GIZ) GmbH, available at: https://herandnow.in/wp-content/ uploads/2021/07/HerNow-Report-on-Women-Entrepreneurs-Resilience-in-Times-of-Covid-19.pdf (accessed 12 September 2021).

Fafchamps, M., \& Quinn, S. (2018). Networks and manufacturing firms in Africa: Results from a randomized field experiment. The World Bank Economic Review, 32(3), 656-675.

Galiani, S., Meléndez, M., \& Ahumada, C. N. (2017). On the effect of the costs of operating formally: New experimental evidence. Labour Economics, 45, 143-157.

W. B. Gartner, W. C. Gartner, K. G. Shaver, N. M. Carter, \& P. D. Reynolds (Eds.) (2004). Handbook of Entrepreneurial Dynamics: The Process of Business Creation. Sage.

Gindling, T. H., \& Newhouse, D. (2014). Self-employment in the developing world. World Development, $56,313-331$.

Gupta, S. and Aggarwal, A. (2015), Opportunities and challenges faced by women entrepreneurs in India. IOSR Journal of Business and Management (IOSR-JBM). 17(8). Ver. III (August 2015), 69-73. e-ISSN: 2278-487X, p-ISSN: 2319-7668, available at: www.iosrjournals.org (accessed 29 September 2021).

Hess, J., Klapper, L., \& Beegle, K. (2021). Financial inclusion, women, and building back better. The World Bank. available at: https://openknowledge.worldbank.org/bitstream/handle/10986/35870/ Financial-Inclusion-Women-and-Building-Back-Better.pdf? sequence $=1 \&$ isAllowed $=\mathrm{y}$ (accessed 14 September 2021).

ICRW (2014). Gender Issues in the Micro, Small and Medium Enterprises (MSMEs) Sector in India. Submitted to The World Bank. available at: https://openknowledge.worldbank.org/bitstream/ handle/10986/28531/119304-WP-IN-TF013641-Gender-in-MSME-Aug-2014-PUBLIC.pdf? sequence $=1 \&$ isAllowed $=y$ (accessed 12 September 2021).

Jayachandran, S. (2020). Microentrepreneurship in developing countries. Working Paper 26661, available at: http://www.nber.org/papers/w26661 (accessed 14 October 2021).

Kabbaj, M., Hadi, K. E. Q. E., Elamrani, J., \& Lemtaoui, M. (2018). A study of the social entrepreneurship ecosystem: the case of Morocco. Journal of Developmental Entrepreneurship, 21(4).

Karim, N. A. (2001). Jobs, gender and small enterprises in Bangladesh: Factors affecting women entrepreneurs in small and cottage industries in Bangladesh. International Labour Organization, Seed Working Paper, No. 14, pp. 1-115.

Kjeldsen, J. I., \& Nielson, K. T. (2000). The circumstances of women entrepreneurs, Copenhagen. Danish Agency for Trade and Industry, available at: http://www.ebst.dk/publikationer/ rapporter/women_entrepreneurs/index-eng.html. 
FREP 1,2
Klapper, L. F., \& Parker, S. C. (2011). Gender and the business environment for new firm creation. The World Bank Research Observer, 26(2), 237-257.

KMPG (2020). Government and institution measures in response to COVID-19, available at: https:// home.kpmg/xx/en/home/insights/2020/04/india-government-and-institution-measures-inresponse-to-covid.html (accessed 6 September 2021).

Kritikos, A. S. (2014). Entrepreneurs and their impact on jobs and economic growth, available at: https://wol.iza.org/articles/entrepreneurs-and-their-impact-on-jobs-and-economic-growth/long (accessed 12 March 2019).

Lenka, U., \& Agarwal, S. (2017). Role of women entrepreneurs and NGOs in promoting entrepreneurship: Case studies from Uttarakhand, India. Journal of Asia Business Studies, 11(7), doi: 10.1108/JABS-07-2015-0088.

Loayza, N. V., \& Pennings, S. (2020). Macroeconomic policy in the time of covid-19: A primer for developing countries. Research and Policy Briefs From the World Bank Malaysia Hub, 28, March 26, 2020, available at: https://documents1.worldbank.org/curated/en/951811585836124198/pdf/ Macroeconomic-Policy-in-the-Time-of-COVID-19-A-Primer-for-Developing-Countries.pdf (accessed 5 September 2021).

Lundberg, S., \& Rose, E. (1999). The Determinants of Specialization within Marriage. Hong Kong: School of Economics and Finance, University of Hong Kong.

Maysami, R. C., \& Goby, V. P. (1999). Female business owners in Singapore and elsewhere: A review of studies. Journal of Small Business Management, 37(2), 96.

Mehrotra, S., \& Giri, T. (2019). The size structure of India's enterprises: Not just the middle is missing. CSE working paper No 25. Centre for Sustainable Employment, Azim Premji University, available at: https://cse.azimpremjiuniversity.edu.in/wp-content/uploads/2019/12/Mehrotra_ Giri_Not_Just_Missing_Middle_Revised_July2020 (accessed 15 September 2021).

Memon, A. (2020). Analyzing the entrepreneurial ecosystem for women entrepreneurs: A study of rural Jamshoro, Pakistan. Indian Journal of Commerce and Management Studies, 11(3), 45-59.

Milazzo, A., \& Goldstein, M. (2019). Governance and women's economic and political participation: Power inequalities, formal constraints and norms. The World Bank Research Observer, 34(1), 34-64, doi: 10.1093/wbro/lky006, February 2019.

Mint (2020). Covid-19 impact on women-led micro biz widens socio-economic gap: report, 29 November, available at: https://www.livemint.com/news/india/covid-19-impact-on-women-ledmicro-biz-widens-socio-economic-gap-report-11606632342518.html.

Misra, S. S., \& Tejas, P. (2021). The inequality virus: India supplement 2021, 22 January, available at: https://www.oxfamindia.org/press-release/inequality-virus-india-supplement-2021 (accessed 17 September 2021).

MSME (2021). Annual report: 2020-2021. Ministry of Micro, Small and Medium Enterprises (MSMEs), Government of India. available at: https://msme.gov.in/sites/default/files/MSMEANNUAL-REPORT-ENGLISH\% 202020-21.pdf (accessed 16 September 2021).

NITI Ayog (2021). Moving the needle: The women entrepreneurship platform, available at: https:// www.niti.gov.in/sites/default/files/2021-03/MovingTheNeedle_08032021-compressed.pdf (Accessed 10 October 2021).

Nix, E., Gamberoni, E., \& Heath, R. (2016). Bridging the gender gap: Identifying what is holding selfemployed women back in Ghana, Rwanda, Tanzania, and the Republic of Congo. The World Bank Economic Review, 30(3), 501-521.

NSCI (2021). Badhate Kadam. News letter, February 2021, available at: https://www.nsic.co.in/pdfs/E_ Newsletter/Badte_Kadam_03022021_Final.pdf (accessed 17th October 2021).

OECD (2020). OECD policy responses to coronavirus (COVID-19): Women at the core of the fight against COVID-19 crisis, Version 1st April 2020, available at: https://www.oecd.org/ coronavirus/policy-responses/women-at-the-core-of-the-fight-against-covid-19-crisis-553a8269/ (accessed 28 Septmber 2021). 
Pandey, R., \& Pillai, A. (2020). Covid-19 and MSMEs: The 'identification' problem. Ideas for India, available at: https://www.ideasforindia.in/topics/macroeconomics/covid-19-and-the-msmesector-the-identification-problem.html (accessed 15 September 2021).

Rajat, P. (2020). Forces must shun imports, go for 'make in India', says Gen Bipin Rawat. The Times of India, available at: https://timesofindia.indiatimes.com/india/forces-must-shun-imports-go-formake-in-india-says-gen-bipin-rawat/articleshow/75652962.cms (accessed 10 May 2020).

Reynolds, P. D., Reynolds, P. D., \& White, S. B. (1997). The Entrepreneurial Process: Economic Growth, Men, Women, and Minorities, Praeger.

Rothenberg, A. D., Gaduh, A., Burger, N. E., Chazali, C., Tjandraningsih, I., Radikun, R., .. . Weilant, S. (2016). Rethinking Indonesia's informal sector. World Development, 80, 96-113.

Sethi, J. (1998). Women and development - a case for development of women entrepreneurship with special reference to Indian women. India Quarterly, January-June, 53-60.

Sharma, M. (2020). Govt announces atmanirbhar bharat 3.0; claims Covid stimulus now worth Rs 29.8 lakh crore. Business Today, 12 November, available at: https://www.businesstoday.in/latest/ corporate/story/govt-announces-atmanirbhar-bharat-30-covid-stimulus-worth-rs-29-lakh-crore278508-2020-11-12.

Singh, N. (2019). Nationalist's perspective on the question of women's identity. In Y. Chinna Rao (Ed.), Perspectives on Social Exclusion: Essays in Honour of Professor Sabyasachi Bhattacharya (pp. 142-162). New Delhi: Meena Publication.

Singh, N. (2020). Naari Shakti and women's agency in the politics of India. In N. H. Akhtar, \& P. Jolly (Eds.), Women's Voice: A Search for Feminist Consciousness (pp. 456-470). Dhaka: Parvez Hossain.

Singh, N. (2021). Ambedkar and the question of identity of women. In S. Singh, \& N. Saini (Eds.), Sociology of Marginalised Communities (pp. 144-152). Chandigarh: New Era Publication.

Singh, S., \& Saxena, S. C. (2000). Women entrepreneurs of eastern UP: Challenges and strategies of empowerment. Indian Journal of Industrial Relations, 36(1), 67-68.

Singh, S., Farooquee, N. A., \& Pattanaik, B. K. (2017). Food security, gender, and occupational seasonality in urban low-income households. International Public Health Journal, 9(3), 267-274.

Sunil, S. (2020). India's women entrepreneurs see survival by remodeling business. Economic Times, 19 October, available at: https://economictimes.indiatimes.com/small-biz/entrepreneurship/ indias-women-entrepreneurs-see-survival-by-remodeling-business/articleshow/78741082.cms (accessed 3 September 2021).

Tankha, R. (2020). Voices from the Field: Impact of Covid-19 on Women and Their Collectives in India. Initiative for What Works to Advance Women in The Economy (IWWAGE), an Initiative of LEAD, New Delhi: Krea University.

Taylor, R., \& Newcomer, J. (2005). Characteristics of women small business owners. In S. Fielden, \& J. Davidson (Eds.), International Handbook of Women and Small Business Entrepreneurship. Northampton, Massachusetts: Edward Elgar Publishing.

The Economic Times (2020). FM Nirmala Sitharaman announces Rs 1.7 lakh crore relief package for poor, available at: https://economictimes.indiatimes.com/news/economy/policy/fm-nirmalasitharaman-announces-rs-1-7-lakh-crore-relief-package-for-poor/articleshow/74825054.cms? $u t m \_s o u r c e=$ contentofinterest\&utm_medium $=$ text\&utm_campaign $=$ cppst $\quad($ accessed 15 September 2021).

The World Bank (2020a). World bank fast-tracks $\$ 1$ billion covid-19 (coronavirus) support for India, available at: https://www.worldbank.org/en/news/press-release/2020/04/02/world-bank-fasttracks-1-billion-covid-19-support-for-india (accessed 22 September 2021).

The World Bank (2020b). South Asia Economic Focus, fall 2020: Beaten or Broken? Informality and Covid-19. Washington DC. available at: https://openknowledge.worldbank.org/handle/10986/ 34517 (accessed 20 September 2021).
Challenges of women entrepreneurs 
FREP 1,2
Thomson, E. (1990). Two into one: structural models of couple behavior. In T. W. Draper, \& A. C. Marcos (Eds.), Family Variables. Conceptualization, Measurement, and Use, (pp. 129-142). Newbury Park, London, New Delhi: Sage.

Torres, J., Maduko, F., Gaddis, I., Iacovone, L., \& Beegle, K. (2021). The Impact of the COVID-19 Pandemic on Women-led Businesses. Washington, DC: World Bank.

Udyam (2021). Analysis of Udyam Registration Data (MSME Registered up to 30th June, 2021). Delhi: Office of Development Commissioner (MSME), Ministry of Micro, Small and Medium Enterprises, Government of India.

UN Women (2020). COVID-19 and its economic toll on women: The story behind the numbers, Wednesday, 16 September 2020, available at: https:/www.unwomen.org/en/news/stories/2020/ 9/feature-covid-19-economic-impacts-on-women (accessed 25 September 2021).

UN Women (2021). Your questions answered: Women and covid-19 in India, available at: https://www. unwomen.org/en/news/stories/2021/7/faq-women-and-covid-19-in-india (accessed 6 September 2021).

UN Women and UNDP (2020). COVID-19 Gender Response Tracker. Global Fact Sheet, Version 1 (September 28). New York, NY: United Nations.

\section{About the authors}

Dr Sanjeev Kumar (MA, M Phil, PhD), Assistant Professor, teaches at the Department of Political Science, Shyama Prasad Mukherji College, University of Delhi, since 2015. His research areas are Indian political thought, understanding Ambedkar, political theory, gender studies and research methodology. Sanjeev Kumar is the corresponding author and can be contacted at: sanjeev.spmcollege@gmail.com

Dr Neha Singh (MA, M Phil, PhD), Assistant Professor, teaches at the Department of Political Science, Mata Sundri College, University of Delhi. Her research areas are Indian politics, social exclusions and inclusion, gender studies and political thought.

For instructions on how to order reprints of this article, please visit our website:

www.emeraldgrouppublishing.com/licensing/reprints.htm

Or contact us for further details: permissions@emeraldinsight.com 